\title{
Effect of Talent Management and Organizational Culture on the Performance of Employees (Study on Employee Brantas Abipraya Company, Jakarta)
}

\author{
U. Srihandayani *, K. Kusnendi \\ Universitas Pendidikan Indonesia \\ Bandung, Indonesia
}

\begin{abstract}
Talent management is a complex procedure for the organization but organization needs talented employees to maximize reviews their organizational performances. Talent management involves positioning the right people in the right jobs. This ensures that the employees maximize Reviews their talent for optimal success of the organization. The aim in this study is to investigate the relationship between talent management and organizational culture among the employee performance of Brantas Abipraya Company, The method used is descriptive quantitative. The type of the data needed is primary for the data and secondary data. The number of respondents as many as 35 managers. While the data was collected through questionnaire, surveys, interviews and literature review. Data analysis techniques used descriptive analysis and simple linear regression analysis.
\end{abstract}

Keywords-Talent Management; Organizational Culture; Performance Employee

\section{INTRODUCTION}

AFTA in force since the year 2013 marked the commencement of the free market where the free market imposed goal to streamline and efficient customary international trade. Economic globalization and the arrival of an era of change in the face of free trade is a serious challenge for leaders in managing the organization. In face up change, there needs to be a caution to be able to adjust to developments while maintaining the continuity of the organization in order to survive.

Moreover entering the middle of the second decade of the millennium, several companies have begun to predict what will happen in 2020. This prediction is a preventive measure to prepare the steps and strategies that the company must take in order to remain in the expected business position. The prediction is related to the current management challenges, namely winning the talent war.

Talent war is a situation where companies compete against their competitors to get the best talent in the labor market. This has consequences for the company to be able to do the talent selection process and be more skilled at developing existing talent.

This talent war triggers labor piracy in companies in Indonesia and the world. In order to get the best workforce, the company hires labor. One of the causes of labor piracy is the scarcity or imbalance between the existence and needs of human resources according to the needs of the company.

Piracy seems to be legitimate and commonly done by using money that is not even a little irrational to obtain quality human resources in a short time. The company will experience a huge loss in terms of financial, energy and time if the human resources with the best talents are taken by other companies. The development of the company is hampered because it has to find new human resources that need to be formed and developed from the beginning by the company.

The problem is how to attract, develop and maintain talented human resources by seeing the real conditions in Indonesia at this time. [1] argued that talent management affects the performance of the staff of a bank in the Iranian Kargaran. [2] revealed the influence of talent management on employee performance. [3] revealed the influence of talent management on the performance of employees of oil companies in Iran. Likewise, [4] revealed the influence of talent management on the performance of researchers in the faculty. Of all the researchers above they wrote about the influence of talent management on oil companies, banks and campuses. This is interesting for researchers to write more about talent management in one of the construction companies in Indonesia. We know that construction companies are currently developing very rapidly with massive infrastructure development carried out by the government. The number of jobs/projects that must be handled by the construction company requires the company to be able to have talented employees and retain talented employees not to be hijacked by other construction companies.

Talent management is a series of processes by a company to identify, develop, maintain, and place the right people in the right place. In addition to talent management, organizational culture also plays a role in improving organizational performance and employee performance. [5].

The human and efficiently resource potential of this great, if they can be utilized effectively, would be beneficial to support a sustainable national development rate. To support the development of quality human resources, it takes a quality education, the provision of various social facilities and adequate jobs. The main challenge is how to create a real human resource to produce an optimum performance to achieve the objectives of a company. 


\section{LITERATURE REVIEW}

Employees are an important resource for the company because it has the talent, energy, and creativity that is needed by the organization to achieve its objectives. Employees are the key determinant of the success of the company. For any employee other than required to have the knowledge, skills, and abilities, must also have the experience, motivation, selfdiscipline, and morale is high, so if the employee's performance is good then the performance of the company will also increase the lead to the achievement of corporate goals.

Achievement of corporate goals requires a good human resource management, that human resource management is based on the view that human resource is the primary resource and the company's performance much depends on this, the implementation of policies and effective HR processes will impact substantially on the company's performance.

Performance is a very important thing for any organization or company. [6] states that there are several factors that affect the performance of HR such as individual factors, factors of leadership, team factors, system factors, and situational factors. The first factor that affects the performance of individual employees is a factor that includes knowledge, and talent as the ability of the individual from birth.

At first, Organizational culture is not in demand by those nonacademic, because they do not believe that has had enormous influence on organizational performance. However, after research conducted by universities and consultants such as Harvard, Stanford, MIT, McKinsey, and MAC started to feel the importance of that which they call the corporate culture or the culture of the organization. Their premise through the results of three studies, among others, research on Japanese companies that continuously outperform competitors from the United States, American companies that still have a good performance in the middle of the intensification of business competition heated up since the 1970s, and the company are struggling to develop and implement a strategy to face the new competitive environment.

The corporate culture can provide considerable influence, particularly if the culture is strong strong corporate culture can affect the performance of the employees that will ultimately improve the company's performance and can improve the competitiveness of the company.

The study was conducted at the head office of Brantas Abipraya Company.The company is one of the seven (7) SOE works under the auspices of the minister of state. The reason for the selection of research sites, due to Brantas Abipraya Company is one of the companies that implement talent management and cultivation organizations to manage human resources in order to achieve maximum performance. The purpose of this study was to obtain information and analyze the influence of talent management and organizational culture on employee performance, either jointly or partial.

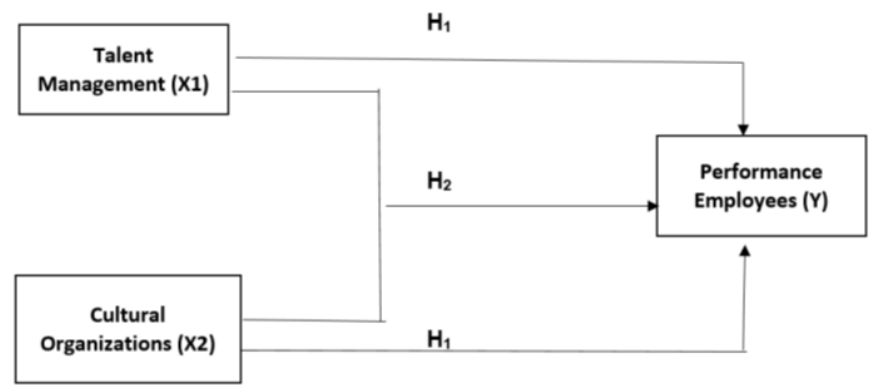

Figure 1. Research model.

\section{Methodology}

This research uses an explanation or explanatory research study with a quantitative approach. This study will be carried out in the company of Brantas Abipraya Company located at Jalan DI Panjaitan Kav 14 Cawang.

The target population in this study are all managers in the headquarters of Brantas Abipraya Company which amounts to 35 managers.

\section{RESULTS AND DISCUSSION}

A. Implementation of talent management

Talent management practices in Brantas Abipraya Company Head Office Cawang-Jakarta, carried out by a special section which is under the auspices of the field of Human Resources and Organization. The definition of talent management is to manage the assets according to the company's human resources that add value or contribution to the company's performance. The program aims to select those that are considered appropriate and has the potential to contribute to improving the performance of the company.

As for the practical implementation of talent management at Brantas Abipraya Company Head Office Cawang consists of several stages, including:

Employee Talent Mapping, serves to identify employees who have the potential and competence in accordance with predetermined criteria; Employee Development talented, development and cultivation of talented employees are done so that employees in accordance with the company's expectations as well as having the readiness for structural positions are nominated; Staffing talented, Employees placed according to their talents, potentials, and competencies that are expected to contribute the maximum to improve company performance; Retaining talented employees, the Company provides financial and non-financial rewards based on performance in an effort to maintain employee motivation and loyalty.

B. Implementation of organizational culture

The practice of organizational culture on Brantas Abipraya Company Head Office Cawang-Jakarta, starting with 
Management (X1) and Cultural Organization (X2) effect by $44.1 \%$ to variable employee performance (Y). While the remaining $55.9 \%$ is influenced by other variables that are not addressed in this study.

E. F test results

Based on the calculation of $F$ test statistic obtained the value of F> F table (14.431> 3.15) and the Sig 0,000b $<0: 05$ so that it can be concluded that the Talent Management (X1) and Cultural Organization (X2) significantly together with the Employee Performance (Y).

\section{CONCLUSION}

Based on the results of statistical analysis known that the Talent Management and Organizational Culture significant effect along the Employee Performance. The results of this study reinforce the theory [7] which states that ideally talent management should run concurrently with the four important strategies more become a basic necessity and a boon for the company, the talent management as a strategy for managing a series of planning, strategy to support the company's strategy, a strategy to develop employees and strategies to retain employees.

Strong organizational culture may affect employee performance. Results pens his reinforce the theory Hofstede elitist [8], Strong organizational culture can encourage the behavior of its employees and other elements of the company to improve its performance, so as to improve company performance.

\section{REFERENCES}

[1] Sadri, A. Pirouz, H. Sharifi, S. \& Farhadi, M. 2015. Studying the Impact of Talent Management on Performance of Staffs. International Academic Journal of Economic, 2(11).

[2] Mensah, J.K. 2015. A "coalesced framework" of talent management and employee performance: For further research and practice. International Journal of Productivity and Performance Management, 64(4): 544-566.

[3] Tash, M. S. Ali, E.N.C. \& Ahmadzadeh, M. 2016. The Effects of Talent Management on Employees Performance in Oil Jam Petrochemical Complex (Oil JPC): The Mediating Role of Job Satisfaction. International Journal of Economics and Finance, 8(6): 226.

[4] Eghbal, F., Hoveida, R., Seyadat, S.A.S., Samavatyan, H. \& Yarmohammadian, M. H. 2017. The effect of talent management process on the research performance of faculty members with the mediating role of organizational justice. Foresight and STI Governance, 11(2).

[5] Kotter, J.P. \& Heskett, J. 1998. Corporate Culture and Performance. (M Benjamin, Ed.) (Translation). PT. Prenhalindo.

[6] Mahmudi. 2004. Manajemen Kinerja Sektor Publik. Yogyakarta: UPP AMP YKPN.

[7] Venkateswaran, N. 2012. Adopting Strategies for Talent Management Issues in Software Companies. International Journal of Management, Economics and Social Sciences, 1(2): 33-41.

[8] Hofstede, G. 1980. Culture's Consequences: International differences in work-related values. Sage: London will increase employee performance.

D. The coefficient of determination (R2)

Based on the calculation results obtained statistically adjusted R2 of 0.441 , so it can be concluded that the Talent 